\title{
Chloride attack evaluation on concrete compositions according to Brazilian standard ABNT NBR 6118 specification
}

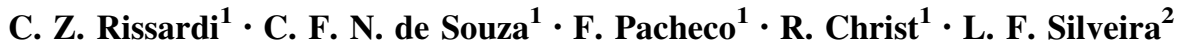

Received: 30 June 2016/Accepted: 7 September 2016/Published online: 1 December 2016

(C) Springer International Publishing Switzerland 2016

\begin{abstract}
One of the factors that affect the concrete structures durability is the corrosion in reinforcement steel. This phenomenon does not occur because of the physical and chemical protection that concrete offers. Among the factors that cause the degradation of reinforced concrete, the ingress of chloride ions stands out. This phenomenon reproduction in laboratory is difficult because of its time for natural occurrence. Therefore, researchers created tests that accelerate the ingress of ions inside concrete in order to simulate how this process will occur in real situations. The Salt Spray test, showed by ASTM B117 standard, is one of these tests, which has been widely utilized in the analysis of metal materials, but it is rare in concrete. Thus, this paper aims to evaluate the chloride ions attack behavior on the four concrete mixes showed by ABNT NBR 6118. The samples are prismatic and the ions attack geometry was observed through the longitudinal rupture of the samples, silver nitrate chemical indicator aspersion and image analysis using the softwares, AutoCAD and Arc
\end{abstract}

\author{
C. Z. Rissardi \\ cristyanczr@gmail.com \\ C. F. N. de Souza \\ cnatus@unisinos.br \\ F. Pacheco \\ fernandapache@unisinos.br \\ R. Christ \\ rchrist@unisinos.br \\ L. F. Silveira \\ luizbasto@unisinos.br
}

1 UNISINOS-itt Performance, Sao Joao Batista, Rio Grande do Sul, Brazil

2 UNISINOS-itt Fuse, Sao Joao Batista, Rio Grande do Sul, Brazil
Map 10.3. The samples with and without protection in its ends and two different sizes were utilized. On samples without protection, the combined effect of the ingress by the end and the sides of the samples was observed, adding to its influence on maximum penetration of the chloride ions. The maximum penetrations increased to twice in the analysis by longitudinal rupture, compared to the analysis by the transversal rupture in four heights, because of the heterogeneous profile showed in samples.

Keywords Chloride attack - Corrosion - Accelerate tests . Durability

\section{Introduction}

Because of the reinforced concrete structures early deterioration, added to new competitive needs and civil construction sustainability requirements, the durability and consequently service life expansion has becoming a meaningful demand among the researchers. Nowadays, with the first performance Brazilian standard launch-ABNT NBR 15575:2013 [1], the achievement of these requirements proved to be even more important. The durability starts to be required as a sustainability requirement, considering the significant amount of construction and demolition waste, the impact coming from construction and its deterioration.

Lupint et al. [2] comment that on developed countries, over $50 \%$ of the money invested in infrastructure projects are applied for structures restoration and recovery, which has suffer from their premature deterioration, which occurs in many ways, varying with the use of construction and its insertion environment. Stands out in this universe the deterioration caused by the presence of chloride ions. 
Observing the Brazilian standard ABNT NBR 6118, for design of concrete structures, it is denoted the special attention dedicated to concrete exposed to salt spray and marine environment. For such sites, it is greater the requirement for compressive strength, cement consumption and lower water/cement ratio (NBR 6118 and NBR 12655) comparing with other classes [3, 4]. This technical specification agrees with the main international standards, understanding the marine environment aggression as severe and intense against concrete.

Tutti [5] proposed a simplified model to steel corrosion, which consider that this process occurs in two phases: initiation and propagation. At first phase, of initiation, the aggressive agents penetrate into concrete covering until reach the bars, causing its depassivation. At second stage, of propagation, the corrosion really settles, causing the degradation of reinforced concrete. At this stage is possible to verify reduction of bars and its concomitant expansion. The reduction causes loss of bearing capacity, while expanding cause internal pressures and therefore, cracking.

The penetration of aggressive agents occurs primarily by air trapped in pores, arising from incorrect processes of concrete density, incorporated air pores obtained by using specific chemical additives and through capillary pores generated by the evaporation of free water present in fresh concrete [6]. Possan (2010) [7] affirms that penetration of aggressive agents depends on concrete permeability and porosity. These, in turn, depends essentially on three factors: concrete quality, concrete recovering thickness and curing conditions.

The chloride ions transport inside concrete is a complicated process and involve ions diffusion, capillary suction, convective flow, added to physical and chemical interactions. In addition to these, there are other factors that also contribute, such as absorption, convection, permeability and water transport through the interior of the concrete while it remains in contact with the water, passing from the water exposed face to dry face. (Luping et al. 2012) [2].

Not only the concrete low permeability, but also the thickness of coatings is an important factor to control the aggressive agents penetration in concrete, since the greater the thickness the greater is the time interval for the aggressive agents reach the surface of the armor [8].

This concrete layer, besides prevent the aggressive agents ingress, likewise avoids the direct contact of the concrete with the external environment. Furthermore, due to the high $\mathrm{pH}$ promoted by concrete, a passivating film involves bars, which prevent its deterioration [9].

Aiming structures quality and covering thickness sufficient for the armor protection guarantee, national and international standards regulate specifications to achieve durability. (NBR 6118 [3], EN 1992-1 [10], AS3600 [11]).
Among the aggressive agents that cause the deterioration of the concrete, stands out the penetration of carbon dioxide, $\mathrm{CO}_{2}$, causing carbonation and chloride ions as the main aggressive agents of armor depassivation [12]. Corrosion triggered by these two agents occurs on differently forms: with carbonation the occurrence widespread. In other way, the chloride ion corrosion occurs in a localized form, or pitting.

According to most researchers, it occurs because the corrosion caused by ions chloride causes the dynamic rupture of the passivating film with repeated events of despassivation and re-passivation until the final armor depassivation [9].

The pitting corrosion leads to mass loss higher than general corrosion, considering that it occurs in isolated areas, however, pitting corrosion can cause highly detrimental effects on armor, because where pitting corrosion occurs there's an amplification of tensile stresses. Furthermore, this occurrence is due to high length/radius of these defects, that affects the resistance of armor fatigue and other side effects [6].

\section{Chloride ions penetration evaluation methods}

Considering that chloride ions migration on concrete interior takes place over many years, its reproduction in laboratory analysis becomes very limited due to the long time demand and its variables of influence that may change over time. In order to more easily determine and control the resistance of a given structure to ions chloride attack were instituted various tests that accelerate this process in medium-and/or short term, to determine the penetration resistance chlorides in a reinforced concrete structure.

Those analyses are based in two process that facilitate the measurement of resistance to chloride penetration, some of them are based on diffusion. Others use the electrical conductivity as a measurable parameter being also a catalyzer at the process. Among the analysis that are based in diffusion as a process that facilitate the chloride ion, stands out the method presented by AASHTO T259Standard Method of Test for Resistance of Concrete Chloride Ion Penetration-Salt Ponding Test [13].

The main methods that use electrical conductivity are presented through standards ASTM C 1202 [14] and NT BUILD 492 [15], also considering the CAIM (Corrosão Acelerada por Imersão Modificada-Accelerated corrosion through modified immersion) [16].

Each method has peculiarities that highlight it positively or negatively towards other methods. These methods differ according to the size of samples, equipment used for analysis, the result type offered, among others [17]. The ASHTO T259 method, for example, requires that sample keep in contact with a solution with $16.5 \%$ of sodium 
chloride $(\mathrm{NaCl})$ in one sample face for 90 days. One disadvantage is that the analyses takes at least 118 days (14 days curing, 14 days drying and 90 days of analyze), and them, the results generate a considerable cost $[17,18]$.

The method showed by ASTM C1202 is a short-term test, which can be done in $6 \mathrm{~h}$; however, it takes a long time for samples preparation. Yet, this test doesn't measures attack cycles but concrete permeability through an electrical pulse on the sample, by applying a constant electrical potential difference.

The total electrical pulse is measure and correlated with the capacity to chloride ions to penetrate into concrete [18]. This analysis has a good interconnection with the method showed by ASHTO T259, however, during the sample preparation, this method has some deficiency as its destructive character and sample heating that can affect the results [19]. Another important aspect is that electrical pulse depends at chemical solution composition, which can variate according to the test results [20].

The method from NT BUILD 942 [15] standard allows the diffusion coefficient measurement, which is correlated to chloride attack resistance capacity [17]. The most critical issues are related to the application of a long-term test, if compared to ASTM C 1202 [14] that can be done in 4 days according to test properties [18].

CAIM Method (Accelerated corrosion by modified immersion) as NTBUILD 492 [15] method induces chloride ions migration into concrete in a sample that has in its interior a steel bar, inducing its corrosion. After this process, is possible to verify the corrosion through the mass measuring of the material and its reduction due to the corrosion process [16].

Considering the peculiarities presented during the new methods development, the adoption of other methods to measure chloride attack become important. Among the alternatives that has been adopted is the process test instituted by standard ASTM B-117-Salt spray [21]. Salt spray test is a worldwide method recognized for its use in the evaluation of corrosion resistance of coated or exposed metal. In this procedure, the samples are exposed to a corrosive environment by checking the mass loss the predominant corrosion modes and the visual aspects arising from the reaction of materials with the salt spray [22].

For concretes, some studies use this method, combining the salt sample exposition with chemical indicator of silver nitrate $\left(\mathrm{AgNO}_{3}\right)$. This indicator shows different coloration for samples attacked and not attacked by ion chloride, being this method easier and faster to apply than the others are.

Thus, aiming to evaluate the procedure of salt spray test on concrete, this study proposed a test with four concrete mixtures provided in ABNT NBR 6118, for their four environmental aggressiveness classes. After 1728 hours (72 days) of exposition on a salt spray environment, the samples where longitudinally tested by compression, and after where applied the chemical indicator of silver nitrate to analyze ions penetration behavior.

Eight prismatic specimens were analyzed having $4 \times 4 \times 16 \mathrm{~cm}$, two belonging to each environmental prescribed aggressiveness class according to NBR 6118 . The ends of the samples were protected with epoxy paint film, applied in two layers, in order to prevent the ingress of chloride ions. There were also evaluate eight specimens of $6 \times 6 \times 18 \mathrm{~cm}$, two specimens for each environmental class, as done previously, being however, applied the protective film of epoxy paint to only half of these samples.

By longitudinal compression test, was conducted an analysis of what would be the maximum attack fronts of chloride ions if the specimens, as done by Pacheco (2016) [23]. For the measurement of the thickness that was attacked by chloride ions was analyzed the feasibility of using ArcMap software 10.3 with Autocad software.

\section{Methods}

\section{Sample preparation}

\section{Materials characterization and mixing proportions}

The cement used was CP-V-ARI, and its particle size distribution was obtained by laser method, using as fluid isopropyl alcohol. The equipment used was Microtrac model S3500. The aggregates used were subjected to tests for their particle size distribution, density and bulk density. Determination of bulk density, specific mass and size distribution of the fine aggregate was obtained through Brazilian standards NBR NM45: 2006 [24], NBR NM 52: 2009 [25] and NBR NM 248: 2003 [26] respectively.

In the case of coarse aggregate the procedures used to determine these characteristics where those specified by ABNT NBR NM 45: 2006 [24], NBR NM 53: 2009 [25] and NBR NM 248: 2003 [26], respectively. The fine aggregate has quartz origin, the coarse aggregate, in turn, is basaltic. The traces were drawn up according to the recommendations contained in NBR 6118 [3] and NBR 12655 [4], as summarized in Table 1.

Table 1 Concrete specification according to ABNT NBR 6118 and ABNT NBR 12655

\begin{tabular}{lllll}
\hline Specification parameter & \multicolumn{4}{c}{ Environmental aggressivity class } \\
\cline { 2 - 5 } & I & II & III & IV \\
\hline Minimum cement consumption & 260 & 280 & 320 & 360 \\
Water/cement maxim relation & 0.65 & 0.60 & 0.55 & 0.45 \\
Compressive strength & C20 & C25 & C30 & C40 \\
\hline
\end{tabular}


Table 2 Super plasticizer properties Source BASF (2016)

\begin{tabular}{llll}
\hline Technical information & & \\
\hline $\begin{array}{l}\text { Function } \\
\text { Chemical base }\end{array}$ & $\begin{array}{l}\text { Superplasticizer properties-3 }{ }^{\circ} \text { generation for concrete } \\
\text { Polycarboxylic ether } \\
\text { Liquid } \\
\text { Aspect }\end{array}$ & $\begin{array}{l}\text { Turbid white } \\
\text { Water reducer }\end{array}$ \\
Color & Total & Unit \\
Second action & \multicolumn{2}{c}{ Specification } \\
Water solubility & BASF method & Liquid turbid white & Visual \\
\hline Testes & TM 761B & $05 /$ jul & - \\
\hline Appearance & TM 112B & $1.067-1.107$ & $\left(\mathrm{gm} / \mathrm{cm}^{3}\right)$ \\
pH & TM 103B & $28.5-31.5$ & $(\%)$ \\
Density & TM 613B & $<150$ & $\mathrm{Cps}$ \\
Solids & TM 117 & &
\end{tabular}

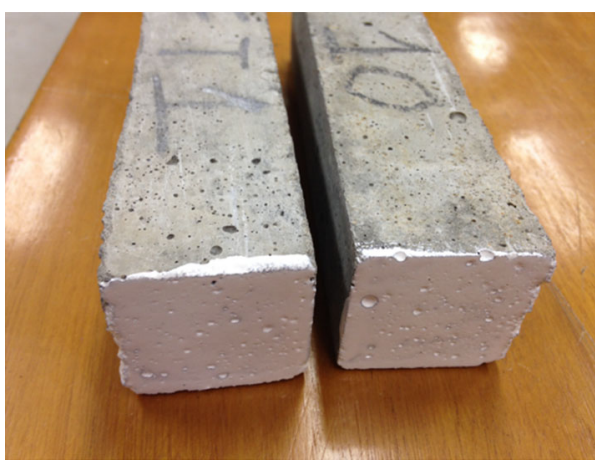

Fig. 1 Protective film on samples borders

It was used $0.87 \%$ of superplasticizer (regarding to cement mass), whose characteristics can be observed at Table 2. Thus, it was found that all traces, even with different values of water/cement ratio the same flow characteristics, classifying as S100, according to ABNT NBR 7212 [27].

\section{Molding cure and sample covering}

Metallic forms were used for samples molding. The molding was performed in two layers; each layer was subjected to 30 impacts using a metal rod. After molded the samples has its surface regularized with metal ruler usage. Later forms were kept in a room with constant temperature and humidity of $25^{\circ} \mathrm{C}$ and $95 \%$, respectively. Completed $24 \mathrm{~h}$ of molding, the test specimens were removed from the forms and stored again in the room with humidity and constant temperature until the age of 28 days. After cured, all $40 \mathrm{~mm}$ specimens and half of $100 \mathrm{~mm}$ specimens received a protective film. This protection was applied to the ends of the specimens as shown in Fig. 1 and it is two coats of epoxy applied using brush, this method was also adopted by Val (2007) [28].

\section{Ensaio de salt spray-ASTM B117}

The chloride attack was realized according to ASTM B 117:2011 [21] procedure. The test chamber was programmed to keep a temperature of $35{ }^{\circ} \mathrm{C}$, the salt solution sprayed has $\mathrm{pH}$ between 6.5 and 7.2, with salt concentration of $5 \%$, considering saturated environment. The samples were inserted in the chamber at the age of 56 days when the test was started. Figure 2 presents the chamber utilized for the tests and samples disposition. Its disposition was made

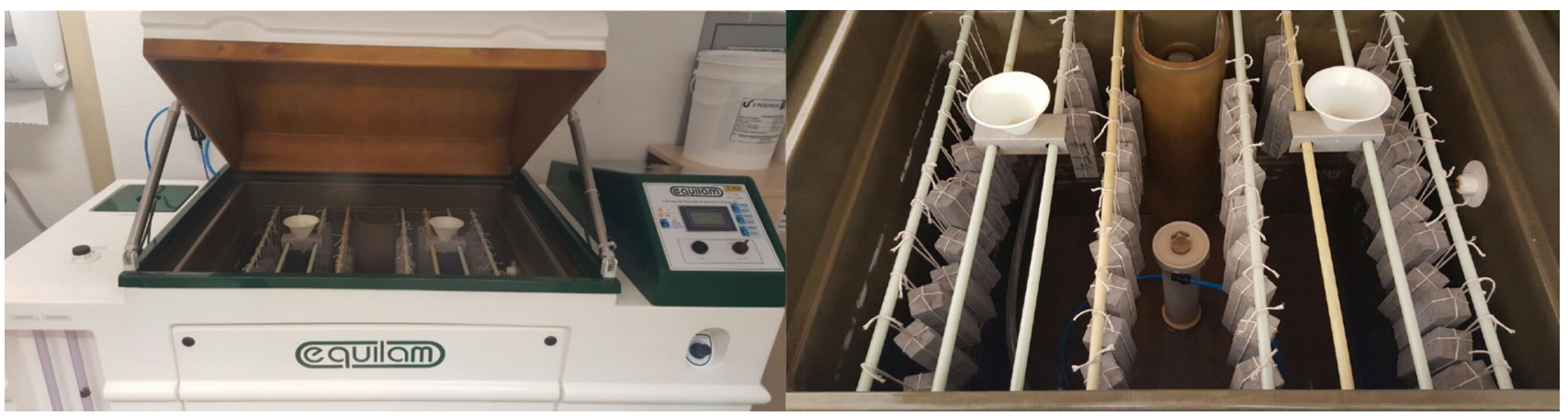

Fig. 2 Cyclic chamber for salt spray test and samples disposition 
Fig. 3 Sample groove and concrete sample after compressive test and chemical indicator spraying
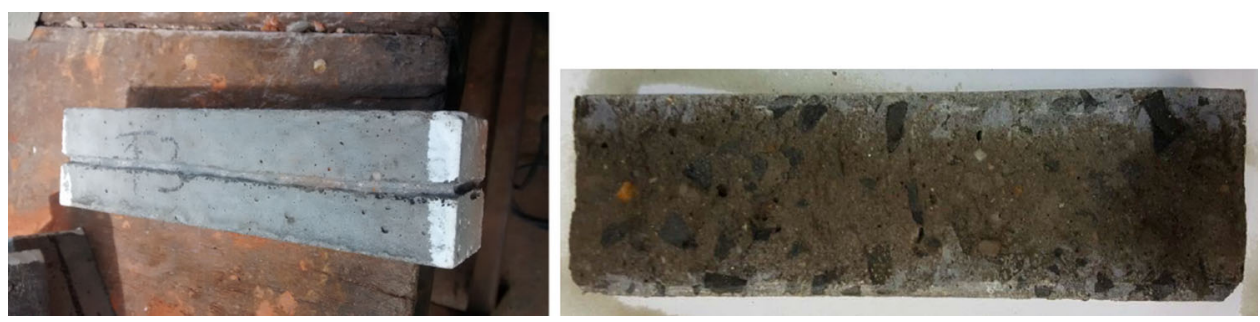

so that there was no drip on the samples and the entire surface of the samples stay in contact with salt spray, this way, thus the samples were kept suspended using a string.

\section{Longitudinal cracking and aspersion of silver nitrate}

Longitudinal compression tests of samples occur after 1728 hours of test (72 days), allowing the evaluation of chloride attack. The compression was made after performing a groove, shown in Fig. 3, which aims to induce the central rupture of the sample. It is noteworthy that the groove and the compressive breakage were not performed on the faces where the sample was regularized, due to the different properties according to that face and the opposite face have, which could induce an error in measurement. Figure 3 also presents a sample after compressive breakage and spraying the chemical indicator (silver nitrate), right after its compressive test. The area which represents brown color indicates that concrete didn't suffer the salt attack. In opposition, the area with concrete natural color represents ion presence.

\section{Image processing in software Arcgis}

It was found that after spraying silver nitrate, concrete doesn't show distinctness of the places where the attack by chloride ions occurred, due to the similarity between colors. Thus, aiming to identify those attacked the software Arc Map 10.3 was used. This tool is applied for images georeferencing and analyses, classifying the images by the identification of tone differences with color classes, specified by users, facilitating the observation of the areas where there is the chloride ions presence. To use this tool, the image is inserted at the software using the tool "Spacial analyst tools". At next configuration, the option Multivariate is choose and then "Iso cluster unsupervised classification". Figure 4 shows the picture with a sample exposed to salt spray and its respective representation with the software.

\section{Front attack measurement by software Autocad ${ }^{\text {TM }}$}

After identify the zones where there is chloride attack by software Arc Map 10.3, it proceeds with the measurement of attack deep. It measurement occurred in two ways, first measuring the attack thickness in four positions, according

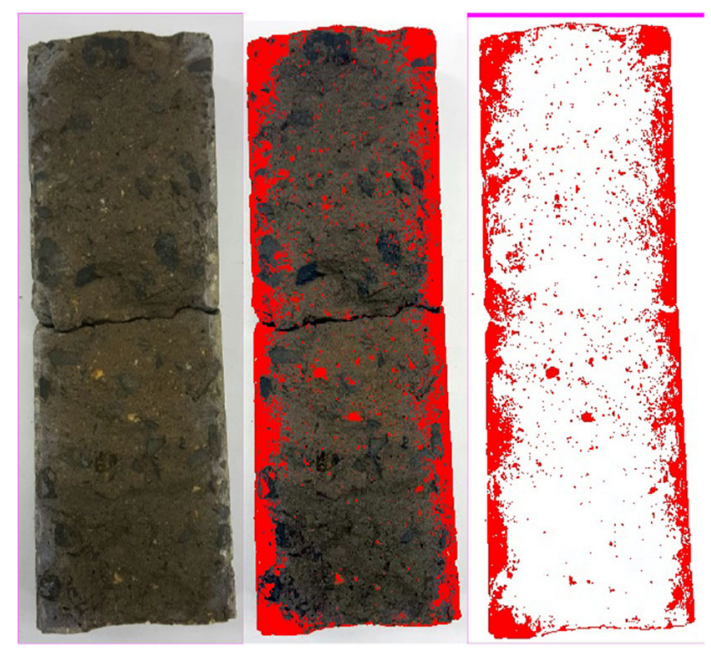

Fig. 4 Pictures with sample identified by programm

to Fig. 5, aiming to discover which depths are achieve at the samples. This measure was made in both sides of the sample, right (R) and left (L). It was also measured the total size of the specimen, to correlate with the deep, reducing the errors due to slope or illumination.

Posteriorly, were measured the different fronts of attack and respectively localization on samples surface. Its localization is made considering the coordinates of the maximum attack point, considering as the reference axis the lowest point of the specimen.

\section{Results}

\section{Materials characterization}

The cement characteristics are observed at Table 3. Particle size distribution is showed at Fig. 6. It was found through these analysis that cement shape is irregular.

Aggregates specific density are presented at Table 4 . Particle size distribution is showed at Table 5 for fine aggregate and Table 6 for coarse aggregate.

\section{Longitudinal cracking}

Even with the groove, some samples did not break at its center and were discarded. Another problem during the 


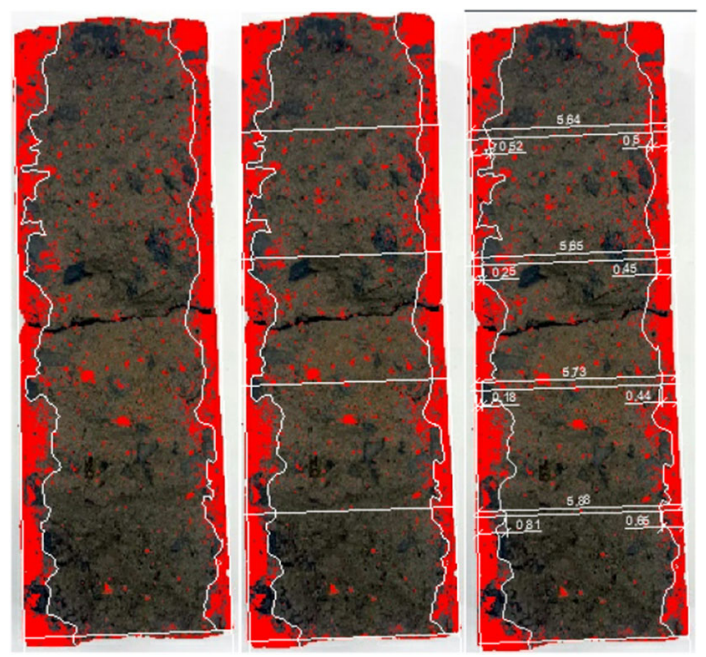

Fig. 5 Chloride ions attack measurement-transversal mode

Table 3 Cements characteristics

\begin{tabular}{|c|c|c|}
\hline Analysis & Standard limits specified & Average value \\
\hline \multicolumn{3}{|l|}{ Chemical analysis } \\
\hline \multicolumn{3}{|l|}{ Levels $(\%)$} \\
\hline $\mathrm{PF}$ & $\leq 4.50$ & 3.63 \\
\hline $\mathrm{MgO}$ & $\leq 6.50$ & 5.94 \\
\hline $\mathrm{SO}_{3}$ para $\mathrm{C}_{3} \mathrm{~A} \leq 8$ & $\leq 3.50$ & 3.03 \\
\hline RI & N/A & 12.28 \\
\hline \multicolumn{3}{|l|}{ Physical analysis } \\
\hline \multicolumn{3}{|l|}{ Fineness (\%) } \\
\hline \#200 & $\leq 6.00$ & 0.00 \\
\hline \#400 & N/A & 1.37 \\
\hline \multicolumn{3}{|l|}{ Blaine } \\
\hline$\left(\mathrm{cm}^{2} / \mathrm{g}\right)$ & $\geq 3000.00$ & $4.875,00$ \\
\hline \multicolumn{3}{|l|}{ Water } \\
\hline$(\%)$ & N/A & 30.78 \\
\hline \multicolumn{3}{|l|}{ Set in time } \\
\hline Start (min) & $\geq 60.00$ & 220.45 \\
\hline End (min) & $\leq 600.00$ & 262.00 \\
\hline \multicolumn{3}{|l|}{ Expandability } \\
\hline$(\mathrm{mm})$ & $\leq 5.50$ & 0.63 \\
\hline \multicolumn{3}{|l|}{ Mechanical analysis } \\
\hline \multicolumn{3}{|l|}{ Compressive strength } \\
\hline 1 day & $\geq 11.00$ & 22.62 \\
\hline 3 days & $\geq 24.00$ & 34.03 \\
\hline 7 days & $\geq 34.00$ & 39.16 \\
\hline 28 days & N/A & 47.56 \\
\hline
\end{tabular}

testes was the cross break in the center of the samples, which ended up complicating the subsequent analysis.

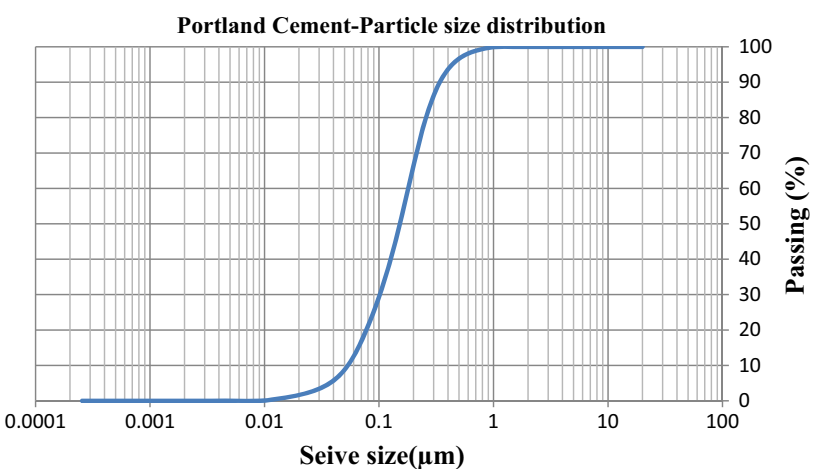

Fig. 6 Portland cement-particle size distribution

\section{Arc Map 10.3 software usage}

The software usage supported the observation of the areas were the chloride attack occurred, although, some problems were perceived. One of the problems showed was that at the background of the image the color was similar to sample color, and them, the program did not recognize the area affected by chloride ions, as showed at Fig. 7. Its influence impede the use of software, them, the measurement was made only with Autocad ${ }^{\mathrm{TM}}$.

Another problem verified was that this tool did not recognize some point attacked, owing to the darkening of some areas due to the presence of shadows, as showed at Fig. 8. It's also possible to verify that aggregates, according to its tone, are recognized by software as attacked zones.

\section{Transversal measurements}

The transversal measurements realized showed a tendency to decrease the chloride-attacked zone with the increase of compressive strength, in other words, the environmental aggressiveness class of each concrete. This behavior is noted in the maximum and medium values found in the samples with size of $6 \times 6 \times 18 \mathrm{~cm}$, these results are demonstrated in the Table 7. In samples with size of $4 \times 4 \times 16 \mathrm{~cm}$, however, the decrease demonstrated in the samples with $6 \times 6 \times 18$ its not easy to be noted, showing even an increase in the chloride attacked zone in the concrete that refers to the environmental aggressiveness class III compared to the concrete that refers to the class II (Table 8).

The maximum value of chloride attack penetration was $1.42 \mathrm{~cm}$ and it was found in the samples with the size of $6 \times 6 \times 18 \mathrm{~cm}$ that refers to the environmental aggressiveness class I. It has noted in the smallest samples a similarity in the measurements of the front of chloride attack for the different classes, making difficult to found 
Table 4 Aggregates specific density

Table 5 Particle size distribution-fine aggregate

\begin{tabular}{lll}
\hline Characteristics & Fine aggregate & Coarse aggregate \\
\hline Specific density & $1.37 \mathrm{~g} / \mathrm{cm}^{3}$ & $1.54 \mathrm{~g} / \mathrm{cm}^{3}$ \\
Bulk density & $2.59 \mathrm{~g} / \mathrm{cm}^{3}$ & $2.64 \mathrm{~g} / \mathrm{cm}^{\circ}$ \\
Specific dry aggregate density & $2.55 \mathrm{~g} / \mathrm{cm}^{3}$ & $2.89 \mathrm{~g} / \mathrm{cm}^{3}$ \\
Density of saturated aggregate with dry surface & $2.57 \mathrm{~g} / \mathrm{cm}^{3}$ & $2.73 \mathrm{~g} / \mathrm{cm}^{3}$ \\
\hline
\end{tabular}

\begin{tabular}{lllll}
\hline $\begin{array}{l}\text { Sieve size } \\
(\mathrm{mm})\end{array}$ & Retained mass & $\begin{array}{l}(\%) \text { of retained } \\
\text { mass }\end{array}$ & $(\%)$ accumulated & $\begin{array}{l}\text { Normal serie } \\
\text { sieves }\end{array}$ \\
\hline 6.3 & - & - & - & - \\
4.8 & 5 & 1 & 1 & 0 \\
2.4 & 15 & 3 & 4 & 0 \\
1.2 & 35 & 7 & 11 & 1 \\
0.6 & 55 & 11 & 22 & 2 \\
0.3 & 130 & 26 & 48 & 31 \\
0.15 & 255 & 51 & 99 & 88 \\
Bottom & 5 & 1 & 100 & 100 \\
Total & 500 & & & 222.16 \\
& Maximum diameter & $4.8 \mathrm{~mm}$ & Fineness & 2.22 \\
& $($ mm) & & modulus & \\
\hline
\end{tabular}

Table 6 Particle size distribution-coarse aggregate

\begin{tabular}{llcll}
\hline $\begin{array}{l}\text { Sieve } \\
\text { size } \\
(\mathrm{mm})\end{array}$ & $\begin{array}{l}\text { Retained } \\
\text { mass }\end{array}$ & $\begin{array}{l}\text { (\%) of } \\
\text { retained } \\
\text { mass }\end{array}$ & $\begin{array}{l}(\%) \\
\text { accumulated }\end{array}$ & $\begin{array}{l}\text { Normal } \\
\text { serie } \\
\text { sieves }\end{array}$ \\
\hline 25 & 0.00 & 0.00 & 0.00 & \\
19 & 0.00 & 0.00 & 0.00 & 0 \\
12.5 & 0.00 & 0.00 & 0.00 & \\
9.5 & 199.60 & 20.00 & 20.00 & 20 \\
6.3 & 480.40 & 48.00 & 68.00 & \\
4.8 & 180.10 & 18.00 & 86.00 & 86 \\
2.4 & 129.90 & 13.00 & 99.00 & 99 \\
1.2 & 9.90 & 1.00 & 100.00 & 100 \\
0.6 & 0.00 & 0.00 & 100.00 & 100 \\
0.3 & 0.00 & 0.00 & 100.00 & 100 \\
0.15 & 0.00 & 0.00 & 100.00 & 100 \\
Bottom & 0.00 & 0.00 & 100.00 & 100 \\
Total & 1000.00 & & & 676.91 \\
& Maximum & 12.50 & Fineness & 6.77 \\
& diameter & & modulus & \\
& (mm) & & & \\
\hline
\end{tabular}

accurate differences, however, easy to find in the biggest samples.

\section{Maximum penetration}

The maximum chloride ions penetrations and their height are demonstrated in the Tables 9,10 and 11, for the biggest

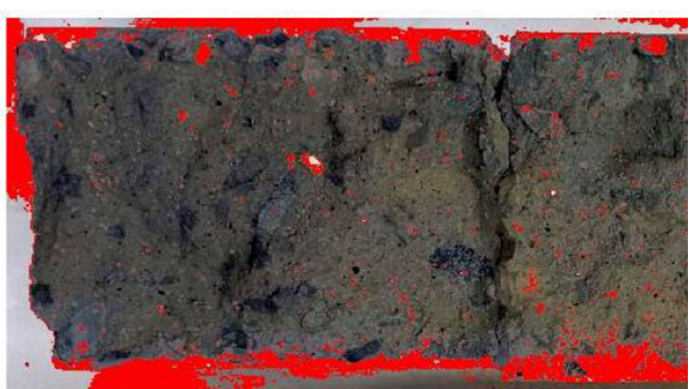

Fig. 7 Bottom influence at analysis through sofware Arc Map 10.3

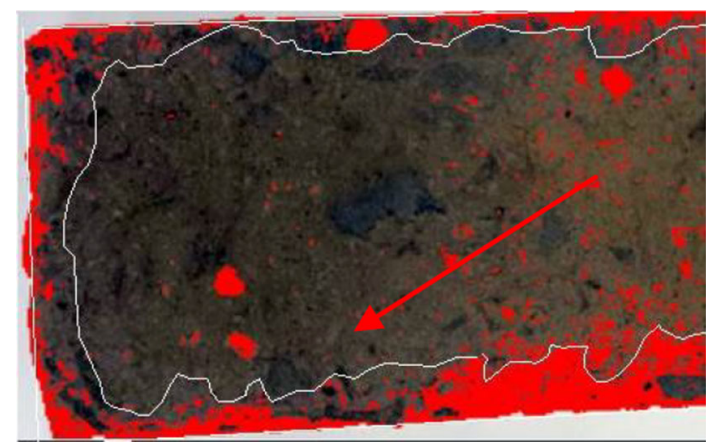

Fig. 8 Zones identified by software as chloride attacked zones

samples with and without protection and for the small samples with protection.

Table 12 shows the increase of the fronts of chloride attack taking into account the maximum measurements 
Table 7 Fronts of chloride attacked, measurements realized according the methodology showed by de Pacheco (2016) [23], samples with the size of $6 \times 6 \times 18 \mathrm{~cm}$

\begin{tabular}{|c|c|c|c|c|c|c|c|c|c|c|c|c|}
\hline \multicolumn{2}{|c|}{ Height position } & \multicolumn{2}{|c|}{$14.40 \mathrm{~cm}$} & \multicolumn{2}{|c|}{$10.80 \mathrm{~cm}$} & \multicolumn{2}{|c|}{$7.2 \mathrm{~cm}$} & \multicolumn{2}{|c|}{$3.6 \mathrm{~cm}$} & \multirow[t]{2}{*}{ Maximum (cm) } & \multirow[t]{2}{*}{ Media (cm) } & \multirow[t]{2}{*}{ Standard deviation } \\
\hline & & $\mathrm{E}$ & $\mathrm{D}$ & $\mathrm{E}$ & $\mathrm{D}$ & $\mathrm{E}$ & $\mathrm{D}$ & $\mathrm{E}$ & $\mathrm{D}$ & & & \\
\hline \multicolumn{13}{|c|}{ Without protection $6 \times 6 \times 18$} \\
\hline \multirow[t]{2}{*}{ I } & Т 11 & 0.60 & 0.87 & 0.31 & 1.17 & 0.29 & 0.82 & 0.24 & 0.51 & 1.42 & 0.82 & 0.37 \\
\hline & $\mathrm{T} 12$ & 0.82 & 1.13 & 1.21 & 0.68 & 1.42 & 0.83 & 1.32 & 0.73 & & & \\
\hline \multirow[t]{2}{*}{ II } & Т 21 & 0.13 & 1.01 & 0.13 & 0.77 & 0.46 & 0.83 & 0.42 & 0.31 & 1.01 & 0.44 & 0.35 \\
\hline & Т 22 & 0.00 & 0.00 & 0.00 & 0.00 & 0.00 & 0.00 & 0.00 & 0.00 & & & \\
\hline \multirow[t]{2}{*}{ III } & Т 31 & 0.20 & 0.32 & 0.15 & 0.36 & 0.83 & 0.52 & 0.00 & 0.46 & 0.83 & 0.31 & 0.20 \\
\hline & T 32 & 0.28 & 0.50 & 0.20 & 0.38 & 0.38 & 0.30 & 0.00 & 0.28 & & & \\
\hline \multirow[t]{2}{*}{ IV } & $\mathrm{T} 41$ & 0.00 & 0.29 & 0.00 & 0.27 & 0.00 & 0.18 & 0.00 & 0.26 & 0.37 & 0.11 & 0.13 \\
\hline & $\mathrm{T} 42$ & 0.37 & 0.17 & 0.24 & 0.10 & 0.00 & 0.12 & 0.00 & 0.00 & & & \\
\hline \multicolumn{13}{|c|}{ With protection $6 \times 6 \times 18$} \\
\hline \multirow[t]{2}{*}{ I } & $\mathrm{T} 11$ & 0.82 & 0.75 & 0.88 & 0.43 & 0.97 & 1.08 & 0.81 & 0.73 & 1.25 & 0.91 & 0.20 \\
\hline & $\mathrm{T} 12$ & 1.25 & 1.21 & 0.94 & 0.94 & 0.91 & 0.68 & 0.91 & 1.01 & & & \\
\hline \multirow[t]{2}{*}{ II } & Т 21 & 0.55 & 0.53 & 0.27 & 0.48 & 0.19 & 0.46 & 0.83 & 0.66 & 0.83 & 0.50 & 0.29 \\
\hline & Т 22 & 0.00 & 0.00 & 0.00 & 0.00 & 0.00 & 0.00 & 0.00 & 0.00 & & & \\
\hline \multirow[t]{2}{*}{ III } & Т 31 & 0.14 & 0.49 & 0.07 & 0.59 & 0.28 & 0.61 & 0.38 & 0.56 & 0.61 & 0.44 & 0.25 \\
\hline & Т 32 & 0.00 & 0.00 & 0.00 & 0.00 & 0.00 & 0.00 & 0.00 & 0.00 & & & \\
\hline \multirow[t]{2}{*}{ IV } & $\mathrm{T} 41$ & 0.17 & 0.00 & 0.00 & 0.37 & 0.15 & 0.11 & 0.19 & 0.24 & 0.37 & 0.16 & 0.12 \\
\hline & $\mathrm{T} 42$ & 0.00 & 0.00 & 0.00 & 0.00 & 0.00 & 0.00 & 0.00 & 0.00 & & & \\
\hline
\end{tabular}

Table 8 Fronts of chloride attacked, measurements realized according the methodology showed by de Pacheco (2016) [23], samples with the size of $4 \times 4 \times 16 \mathrm{~cm}$

\begin{tabular}{|c|c|c|c|c|c|c|c|c|c|c|c|c|}
\hline \multicolumn{2}{|c|}{ Height position } & \multicolumn{2}{|c|}{$12.80 \mathrm{~cm}$} & \multicolumn{2}{|c|}{$9.60 \mathrm{~cm}$} & \multicolumn{2}{|c|}{$6.40 \mathrm{~cm}$} & \multicolumn{2}{|c|}{$3.2 \mathrm{~cm}$} & \multirow[t]{2}{*}{ Maximum $(\mathrm{cm})$} & \multirow[t]{2}{*}{ Media (cm) } & \multirow[t]{2}{*}{ Standard deviation } \\
\hline & & $\mathrm{E}$ & $\mathrm{D}$ & $\mathrm{E}$ & $\mathrm{D}$ & $\mathrm{E}$ & $\mathrm{D}$ & $\mathrm{E}$ & $\mathrm{D}$ & & & \\
\hline \multicolumn{13}{|c|}{ With protection $4 \times 4 \times 16$} \\
\hline \multirow[t]{2}{*}{$\mathrm{I}$} & $\mathrm{T} 11$ & 0.20 & 0.46 & 0.20 & 0.46 & 0.26 & 0.41 & 0.71 & 0.24 & 0.81 & 0.25 & 0.21 \\
\hline & $\mathrm{T} 12$ & 0.24 & 0.24 & 0.24 & 0.24 & 0.81 & 0.65 & 0.13 & 0.56 & & & \\
\hline \multirow[t]{2}{*}{ II } & Т 21 & 0.29 & 0.49 & 0.29 & 0.49 & 0.13 & 0.56 & 0.50 & 0.73 & 0.80 & 0.39 & 0.24 \\
\hline & Т 22 & 0.19 & 0.23 & 0.19 & 0.23 & 0.00 & 0.68 & 0.80 & 0.70 & & & \\
\hline \multirow[t]{2}{*}{ III } & T 31 & 0.68 & 0.29 & 0.68 & 0.29 & 0.65 & 0.32 & 0.92 & 0.33 & 0.92 & 0.51 & 0.21 \\
\hline & Т 32 & 0.56 & 0.53 & 0.56 & 0.53 & 0.49 & 0.09 & 0.30 & 0.36 & & & \\
\hline \multirow[t]{2}{*}{ IV } & $\mathrm{T} 41$ & 0.00 & 0.31 & 0.00 & 0.31 & 0.40 & 0.70 & 0.00 & 0.14 & 0.70 & 0.18 & 0.20 \\
\hline & $\mathrm{T} 42$ & 0.10 & 0.40 & 0.10 & 0.40 & 0.04 & 0.21 & 0.08 & 0.42 & & & \\
\hline
\end{tabular}

Table 9 Maximum fronts of chloride ions attack and their location measured after the longitudinal rupture of the samples with the size of $6 \times 6 \times 18 \mathrm{~cm}$ without protection

\begin{tabular}{|c|c|c|c|c|}
\hline Class & Mixture & Maximum penetration $(\mathrm{cm})$ & Height $(\mathrm{cm})$ & Maximum $(\mathrm{cm})$ \\
\hline \multicolumn{5}{|c|}{ Without protection $6 \times 6 \times 18$} \\
\hline \multirow[t]{2}{*}{ I } & $\mathrm{T} 11$ & 1.75 & 11.14 & \multirow[t]{2}{*}{2.03} \\
\hline & $\mathrm{T} 12$ & 2.03 & 0.84 & \\
\hline \multirow[t]{2}{*}{ II } & $\mathrm{T} 21$ & 1.68 & 1.25 & \multirow[t]{2}{*}{1.68} \\
\hline & $\mathrm{T} 22$ & - & - & \\
\hline \multirow[t]{2}{*}{ III } & $\mathrm{T} 31$ & 1.04 & 17.30 & \multirow[t]{2}{*}{1.04} \\
\hline & $\mathrm{T} 32$ & 0.75 & 16.50 & \\
\hline \multirow[t]{2}{*}{ IV } & T41 & 0.70 & 2.60 & \multirow[t]{2}{*}{0.7} \\
\hline & T42 & 0.45 & 0.55 & \\
\hline
\end{tabular}


Table 10 Maximum fronts of chloride ions attack and their location measured after the longitudinal rupture of the samples with the size of $6 \times 6 \times 18 \mathrm{~cm}$ with protection

\begin{tabular}{|c|c|c|c|c|}
\hline Class & Mixture & Maximum penetration $(\mathrm{cm})$ & Height $(\mathrm{cm})$ & Maximum $(\mathrm{cm})$ \\
\hline \multicolumn{5}{|c|}{ With protection $6 \times 6 \times 18$} \\
\hline \multirow[t]{2}{*}{ I } & $\mathrm{T} 11$ & 1.20 & 5.69 & \multirow[t]{2}{*}{2.44} \\
\hline & $\mathrm{T} 12$ & 2.44 & 0.12 & \\
\hline \multirow[t]{2}{*}{ II } & $\mathrm{T} 21$ & 1.54 & 0.23 & \multirow[t]{2}{*}{1.54} \\
\hline & $\mathrm{T} 22$ & 0.00 & 0.00 & \\
\hline \multirow[t]{2}{*}{ III } & $\mathrm{T} 31$ & 1.21 & 0.84 & \multirow[t]{2}{*}{1.21} \\
\hline & $\mathrm{T} 32$ & 0.00 & 0.00 & \\
\hline \multirow[t]{2}{*}{ IV } & $\mathrm{T} 41$ & 1.15 & 18.00 & \multirow[t]{2}{*}{1.15} \\
\hline & $\mathrm{T} 42$ & 0.00 & 0.00 & \\
\hline
\end{tabular}

Table 11 Maximum fronts of chloride ions attack and their location measured after the longitudinal rupture of the samples with the size of $4 \times 4 \times 16 \mathrm{~cm}$ with protection

\begin{tabular}{|c|c|c|c|c|}
\hline Class & Mixture & Maximum penetration $(\mathrm{cm})$ & Height $(\mathrm{cm})$ & $\operatorname{Maximum}(\mathrm{cm})$ \\
\hline \multicolumn{5}{|c|}{ With protection $4 \times 4 \times 16$} \\
\hline \multirow[t]{2}{*}{ I } & $\mathrm{T} 11$ & 1.01 & 11.00 & \multirow[t]{2}{*}{1.01} \\
\hline & $\mathrm{T} 12$ & 0.98 & 6.82 & \\
\hline \multirow[t]{2}{*}{ II } & $\mathrm{T} 21$ & 0.87 & 12.00 & \multirow[t]{2}{*}{0.89} \\
\hline & $\mathrm{T} 22$ & 0.89 & 7.16 & \\
\hline \multirow[t]{2}{*}{ III } & $\mathrm{T} 31$ & 0.99 & 3.43 & \multirow[t]{2}{*}{0.99} \\
\hline & $\mathrm{T} 32$ & 0.75 & 13.00 & \\
\hline \multirow[t]{2}{*}{ IV } & $\mathrm{T} 41$ & 0.79 & 6.91 & \multirow[t]{2}{*}{0.79} \\
\hline & T42 & 0.50 & 11.45 & \\
\hline
\end{tabular}

Table 12 Thickness attacked by chloride ions increase, considering the measurements through the longitudinal break comparing with the maximum values of attack obtained by Pacheco (2016) [23]

\begin{tabular}{|c|c|c|c|c|c|c|c|c|c|}
\hline \multirow[t]{2}{*}{ Class } & \multicolumn{3}{|c|}{ Without protection $6 \times 6 \times 18$} & \multicolumn{3}{|c|}{ With protection $6 \times 6 \times 18$} & \multicolumn{3}{|c|}{ With protection $4 \times 4 \times 16$} \\
\hline & $\begin{array}{l}\text { Maximum } \\
\text { long }(\mathrm{cm})\end{array}$ & $\begin{array}{l}\text { Maximum } \\
\text { transv. }(\mathrm{cm})\end{array}$ & $\begin{array}{l}\text { Increase } \\
(\%)\end{array}$ & $\begin{array}{l}\text { Maximum } \\
\text { long }(\mathrm{cm})\end{array}$ & $\begin{array}{l}\text { Maximum } \\
\text { transv. }(\mathrm{cm})\end{array}$ & $\begin{array}{l}\text { Increase } \\
(\%)\end{array}$ & $\begin{array}{l}\text { Maximum } \\
\text { long }(\mathrm{cm})\end{array}$ & $\begin{array}{l}\text { Maximum } \\
\text { transv. }(\mathrm{cm})\end{array}$ & $\begin{array}{l}\text { Increase } \\
(\%)\end{array}$ \\
\hline I & 2.03 & 1.42 & 42.96 & 2.44 & 1.25 & 95.91 & 1.01 & 0.81 & 24.36 \\
\hline II & 1.68 & 1.01 & 66.34 & 1.54 & 0.83 & 86.45 & 0.89 & 0.80 & 11.96 \\
\hline III & 1.04 & 0.83 & 25.30 & 1.21 & 0.61 & 99.31 & 0.99 & 0.92 & 7.53 \\
\hline IV & 0.70 & 0.37 & 87.67 & 1.15 & 0.37 & 212.34 & 0.79 & 0.70 & 13.63 \\
\hline Media & - & - & 54.65 & - & - & 97.61 & - & - & 12.80 \\
\hline
\end{tabular}

obtained through transversal rupture, using the methodology adopted by Pacheco (2016) [23] and measurements obtained by the longitudinal rupture.

\section{Chloride attack geometry}

In the Table 13 its demonstrated how has the chloride attack developed in the samples with the size of $6 \times 6 \times 18 \mathrm{~cm}$ without any protection.

The Tables 14 and 15 showed how occurs the ions chloride penetration in the samples protected by an epoxy coat in its ends.

\section{Conclusions}

Based on the realization of this work and the results obtained, its been concluded that:

(1) The software Arc Map 10.3 is an useful tool to identify the zones where the ions chloride are present, however, its necessary to take careful when the pictures are taken, so that, the color of the background, the presence of shadows and the differences of the luminosity don't commit the results obtained.

(2) The results obtained in the samples with the size of $6 \times 6 \times 18$ showed better the concrete quality 
Table 13 Chloride attack geometry in the samples with the size of $6 \times 6 \times 18$ without protection

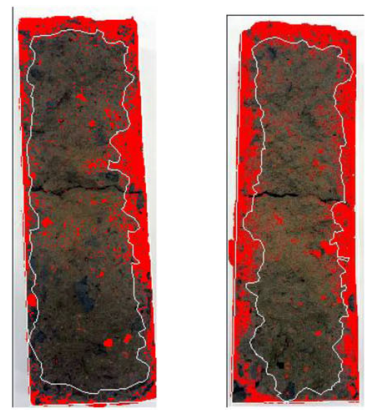

Mixture 1

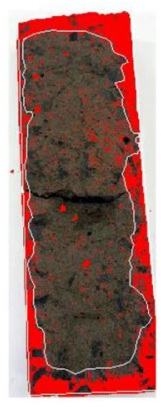

Mixture 2

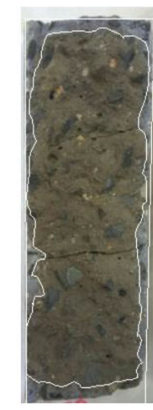

Mixture 3
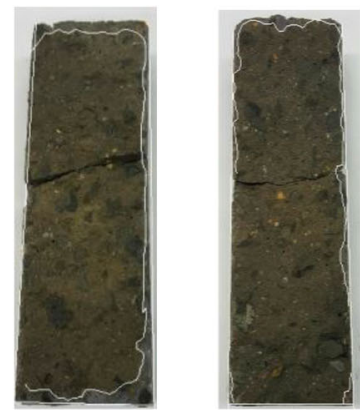

Mixture 4

Table 14 Chloride attack geometry in the samples with the size of $6 \times 6 \times 18$ with protection

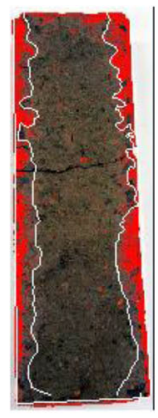

Mixture 1

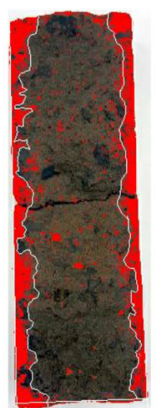

Mixture 2

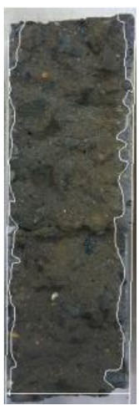

Mixture 3

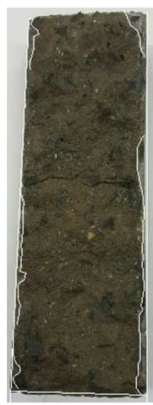

Mixture 4

Table 15 Chloride attack geometry in the samples with the size of $4 \times 4 \times 16$ with protection

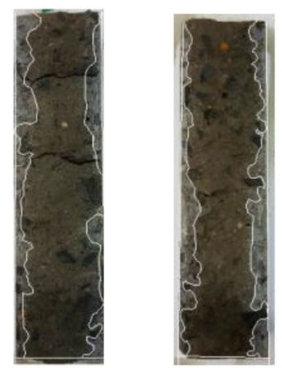

Mixture 1

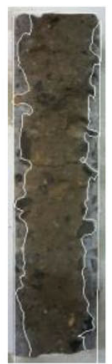

Mixture 2

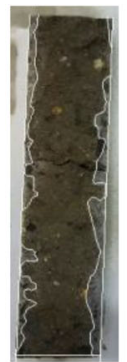

influence against the chloride attack, showing a significant decrease in the ingress of this aggressive agents when the quality of the concrete are increased.

(3) The values obtained in the $4 \times 4 \times 16 \mathrm{~cm}$ samples are different, compared to the values obtained in the $6 \times 6 \times 18 \mathrm{~cm}$ samples, showing a bigger chloride ions penetration in the concrete that refers to the

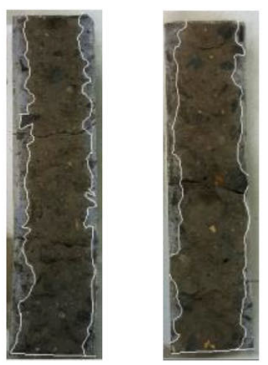

Mixture 3

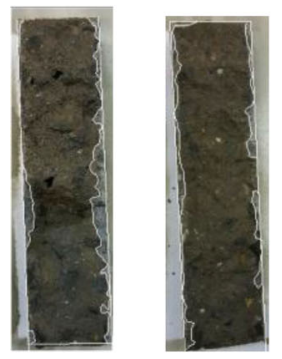

Mixture 4 environmental aggressively class III if compared to the concrete of the classes I and II.

(4) The longitudinal rupture of the samples leading to the discard of some samples, what caused a decrease in the sampling size. So, its recommended by the authors that the utilization of the cylinders samples has to be investigated, because its longitudinal rupture can occur more easily. 
(5) The maximum chloride ion penetration obtained, taking into account, all the longitudinal profile of attack of the samples demonstrated a similar behavior, if compared to the measure obtained by the methodology showed by Pacheco (2016) [23], but with increases. These increases were varied, the $6 \times 6 \times 16$ samples with protection showed the biggest increases. The $4 \times 4 \times 16$ samples showed the lowest values of increases, but, the similarity in the fronts of chloride attack, like was commented before, stay.

(6) In the biggest samples with and without protection its been shown the presence of maximum chloride penetrations, taking into account the longitudinal profile analysis, in high and low heights. In the smallest samples the maximum penetration occurs in the center of the sample.

(7) The geometry of the ions chloride attack in the longitudinal analysis, shows that the chloride penetration values change a lot in few centimeters, making the profile very heterogeneous. In the samples without protection the longitudinal rupture demonstrated the ingress of the chloride ions by the ends, causing a combined effect that increase the front of chloride attack in the corners of the samples.

(8) The utilization of salt spray test showed to be a simple test and easily to execute, however, its necessary studies to the complete understanding of this test in the evaluation of the chloride attack resistance of concrete.

\section{References}

1. Associação Brasileira de Normas Técnicas (2013) NBR 15575-1: Edificações habitacionais-Desempenho Parte 1: Requisitos gerais. Associação Brasileira de Normas Técnicas, Rio de Janeiro, p 71

2. Luping T, Nilsson L, Basheer PAM (2012) Resistance of concrete to chloride ingress: Testing and modelling. CRC Press, Boca Raton, p 238

3. Associação Brasileira de Normas Técnicas (2014) NBR 6118: Projeto de estruturas de concreto-Procedimento. Associação Brasileira de Normas Técnicas, Rio de Janeiro, p 238

4. Associação Brasileira de Normas Técnicas (2015) NBR 12655: Concreto de cimento Portland-Preparo, controle, recebimento e aceitação-Procedimento. Associação Brasileira de Normas Técnicas, Rio de Janeiro, p 23

5. Tuutti K (1982) Corrosion of steel in concrete. Dissertion (Monograph). Swedish Cement and Concrete Research Institute, Kungliga Tekniska Högskolan i Stockholm, Stockholm, p 428

6. Ribeiro DV et al (2014) Corrosão em estruturas de concreto armado: Teoria, controle e métodos de análise. 1st edn. Rio de Janeiro, p 246
7. Possan E (2010) Modelagem da carbonatação e previsão de vida útil de estruturas de concreto em ambiente urbano. 2010. $265 \mathrm{f}$. Dissertação (Mestrado) - Programa de Pós- graduação em Engenharia Civil, Escola de Engenharia, Universidade Federal do Rio Grande do Sul, Porto Alegre

8. Freire K (2005) Avaliação do desempenho de inibidores de corrosão em armaduras de concreto. 2005. 211 f. Dissertação (Mestrado)-Engenharia e Ciências dos Materiais, Setor de Tecnologia, Universidade Federal do Paraná, Curitiba

9. Figueiredo EP, Meira G (2013) BT06-Corrosão das armaduras das estruturas de concreto. ALCONPAT Internacional, Mérida, p 30

10. European Committee for Standardization (2004) EN 1992-1-2: Eurocode 2: Design of concrete structures - Part 1-2: General rules-Structural fire design. European Committee For Standardization, Brussels

11. Australian Standard (2001) Concrete structures. AS3600-2001. Standards Australia, Sydney

12. Cascudo O (2005) Inspeção e diagnóstico de estrutura de concreto com problemas de corrosão da armadura. In: Concreto: ensino, pesquisa e realizações. $2 \mathrm{v}$ ed. Geraldo C. Isaia. IBRACON, São Paulo

13. AASHTO (2002) T-259: Standard method of test for resistance of concrete chloride ion penetration. AASHTO, Washington

14. American Society for Testing Materials (2007) ASTM C1202-07: standard test method for electrical indication of concrete's ability to resist chloride ion penetration. Philadelphia

15. Build NT, Nordtest Method (1999) 492: Concrete, mortar and cement-based repair materials: chloride migration coefficient from non-steady-state migration experiments. Nordtest, Espoo

16. Graeff AG (2007) Avaliação experimental e modelagem dos efeitos estruturais da propagação da corrosão em elementos de concreto armado. 2007. 184 f. Dissertação (Mestrado) - Programa de Pós-graduação em Engenharia Civil, Escola de Engenharia, Universidade Federal do Rio Grande do Sul, Porto Alegre

17. Fedumenti MB (2013) Avaliação da Influência da cinza de casca de arroz no comportamento de concretos com agregado reciclado de concreto em relação a propriedades mecânicas e de durabilidade, com ênfase no transporte de íons cloreto. 2013. $134 \mathrm{f}$. Dissertação (Mestrado)-Programa de Pós-graduação em Engenharia Civil, Universidade do Vale do Rio dos Sinos, São Leopoldo

18. Vivas E, Boyd A, Hamilton HR (2007) Permeability of Concrete-Comparison of Conductivity and Diffusion Methods. University of Florida, Department of Civil and Coastal Engineering, Gainesville

19. Hooton RD (2004) Study of the Joule effect on rapid chloride permeability values and evaluation of related electrical properties of concretes. Cem Concr Res 34:1007-1015

20. Shi C (2003) Another look at the rapid chloride permeability test (ASTM C1202 or ASSHTO T277). FHWA Resource Center, Baltimore

21. American Society for Testing Materials (_2011) ASTM B117: Standard Practice for Operating Salt Spray (Fog) Apparatus

22. Kishimoto I (2010) Experimental Study on the Corrosion Condition of Steel Bars in Cracked Reinforced Concrete Specimen. In: International Symposium on the Ageing Management and Maintenance of Nuclear Power Plants, Tokyo, p 2010

23. Pacheco $F$ (2016) Investigação da relação entre os parâmetros de projeto das estruturas de concreto armado visando a durabilidade. 2016. Dissertação (Mestrado)-Programa de Pós-graduação em Engenharia Civil, Universidade do Vale do Rio dos Sinos, São Leopoldo (dissertação em elaboração)

24. Associação Brasileira de Normas Técnicas-ABNT (2006) NBR NM 45: 2006. Agregados-Determinação da massa unitária e do 
volume de vazios. Associação Brasileira de normas técnicas, Rio de Janeiro

25. Associação Brasileira de Normas Técnicas-ABNT (2009) NBR NM 52: 2009. Agregado miúdo-Determinação da massa específica e massa específica aparente. Associação Brasileira de normas técnicas, Rio de Janeiro

26. Associação Brasileira de Normas Técnicas-ABNT (2003) NBR NM 248: 2003. Agregados-Determinação da composição granulométrica. Associação Brasileira de normas técnicas, Rio de Janeiro
27. Associação Brasileira de Normas Técnicas-ABNT (2012) NBR 7212: Execução de concreto dosado em central-Procedimento. Associação Brasileira de Normas Técnicas, Rio de Janeiro, p 16

28. VAL JG (2007) Avaliação do desempenho de camada protetora em concreto submetido a meio quimicamente agressivo. Dissertação (Mestrado)-Pós-Graduação em Engenharia Civil, Escola de Engenharia, Universidade Federal de Minas Gerais, Belo Horizonte, p 72 